SINIŠA VILKE, M.Sc.

E-mail: svilke@pfri.hr

LIVIA ŠANTIĆ, B.Eng.

E-mail: livia@pfri.hr

University of Rijeka, Faculty of Maritime Studies

Studentska 2, 51000 Rijeka, Croatia

MATIJA GLAD, M.Sc.

E-mail: matija.glad@hrvatske-ceste.hr

Hrvatske ceste d.o.o.

Vončinina 3, 10000 Zagreb, Croatia
Traffic Planning

Preliminary Communication

Accepted: July 14, 2010

Approved: Nov. 15, 2011

\title{
REDEFINING OF THE RIJEKA RAILWAY JUNCTION
}

\begin{abstract}
This paper presents and analyses the redefined Rijeka railway junction. The redefined concept of the Rijeka railroad hub in the context of port and railway interdependence dictates the need to find the accommodation of cargo transport to peripheral locations such as: Krasica, Kukuljanovo, Bakar, Ivani, Bršica and capacity for the island of Krk, while passenger transport would be implemented in the urban area. The most important projects related to Rijeka rail transport system are the construction of a new line of high efficiency between Zagreb and Rijeka, and a new railroad through the tunnel of Učka which will link the ports of Rijeka, Koper and Trieste. Together with the reconstruction of cargo stations Rijeka and Brajdica, an extension of the other tracks on the railroads Škrljevo-Rijeka and Rijeka-Opatija/Matulji should be performed as well as the construction of Krasica, Ivani, Tijani and Vrgljevo stations. The construction includes a multipurpose bridge to the Island of Krk and a railway line to the new container terminal as well as the new railway bypass to "elevation 200".
\end{abstract}

\section{KEY WORDS}

Rijeka railway junction, railway transport system, railway transport, Port of Rijeka

\section{INTRODUCTION}

Spatial and traffic definition of the Rijeka railway junction in the context of rational connection with the wider area of continental hinterland, is in direct function with the strategic orientations of the maritime economy and port policy[1].

Rijeka transport facilities which include the Kvarner Bay with the Island of Krk and part of Istra with Raša and Pula are the starting and target points of the Pan-European branch $V_{B}$ and important segments of the future longitudinal European Adriatic-Ionian corridor. Transverse directional Pan-European branch $V_{B}$ (Rijeka-Karlovac-Zagreb-Budapest) connects Central
Europe with the northern Adriatic or wider with the Mediterranean areas. This transport corridor connects the three Croatian geographic units: central, mountainous and coastal regions.

The objective and purpose of research is to analyze the existing modernization plans of the Rijeka railway junction and to determine their interaction effect on the development of the Port of Rijeka. Due to high congestion and low service level, the existing rail transport facilities represent a bottleneck for the entire Rijeka gateway. Because of insufficient capacity during the nineteen-eighties and -nineties, the railways were a limiting factor for the Rijeka transport development and indirectly for the Port of Rijeka.

Following the problem, the objective and purpose of research, the working hypothesis has been defined, which reads: without the harmonization of the development plans of the Port of Rijeka and the railway junction, which have to be aligned with the planned traffic, it is not possible to ensure rational spatial expansion of the port system and the generation of new rail capacity.

\section{DEVELOPMENT PLANS FOR THE RIJEKA PORT AND RAIL TRANSPORT FORECAST FOR RIJEKA RAILWAY JUNCTION}

The Port of Rijeka has become a land and sea routes junction of the Pan-European branch $V_{B}$ on the Rijeka-Zagreb route, due to its geographical and transport location. This branch has the most important role in the transport system of the Republic of Croatia since it connects the Danube region and the Adriatic, and is also important as a link between Central European countries and the Adriatic and the Mediterranean. The Adriatic orientation of Croatia just highlights the priority of transport connections between the Pannonian and Adriatic region. The Port of Rijeka represents the 
connection point of the Danube region and the Adriatic by the shortest route which is directed through Croatia and is therefore an important factor of the Croatian involvement in the European integrations.

According to the development plan of the Port of Rijeka the largest traffic increase is expected in the container traffic and therefore the investments of upgrading and construction of container terminals are extremely important [11]. The upgrading plan includes the Container terminal Brajdica, while the construction plan includes a new container terminal on the Zagreb quay and a new container terminal on the island of Krk.

The existing container terminal of the Port of Rijeka does not meet the current traffic needs. In the next three years the terminal capacity and transfer performance from ships to terminal will be increased by means of two additional container cranes on the existing south quay, and it is also planned to build a new 328m operative quay with one additional berth. So, by the end of 2012 the Container terminal Brajdica should get new $50,000 \mathrm{~m}^{2}$ of surface area, the sea depth should be $14.5 \mathrm{~m}$ and the total capacity could be 500,000 TEU.

In order to achieve effective coordination of subsystems of railway transport within the integrated and multimodal transportation it is necessary to invest in the railway part of the Brajdica terminal. These construction projects include the railways extension in order to deliver more wagons for containers transportation on the loading tracks and the upgrading of three tracks.

The new container terminal on the Zagreb pier in the western part of the existing port would include in its final development phase 1,400 m of new quay which would be able to berth the most modern container and RORO vessels, while its total traffic should amount to 800,000 TEU per year.

It is estimated that about $60 \%$ of containers should be delivered or despatched by means of railways and about $40 \%$ by trucks [11]. The already constructed rail facilities would be used as railway terminal while the existing tracks which should be placed next to the planned terminal would be used as loading-unloading place for containers.

The construction of a new container terminal on the island of Krk is planned and consequently the construction of a new bridge. The new container terminal on the Island of Krk would be under a free economic zone that would include the existing oil terminal and DIOKI Petrochemical facilities, a new LNG terminal and other business and economic activities. The above mentioned terminal would have a total transfer capacity of more than 2.5 million TEU per year, and should be connected with the mainland thanks to a newly constructed road-rail multipurpose bridge. In order to transport such a container entity to the terminal and the mainland, it is necessary to build a new highefficiency railway line Zagreb-Rijeka of lowland characteristic.

The share of railway transport in delivery/dispatch of cargo from/to the Port of Rijeka in the 1990s amounted to about $90 \%$. The construction of the Rijeka-Zagreb motorway diverted much of the goods to road transport and consequently today the share of railway cargo transport, as an environmentally friendly transport branch, amounts to approximately $30 \%$. Analyzing the container transport, the share of railway in the total inland transport of goods with the source and destination in the Port of Rijeka is between 20 and $25 \%$.

In the Study of construction justifiability for railway State Border-Botovo-Zagreb-Rijeka [12] and the Study of Rijeka railway transport system [14] regarding the dimensioning of the Rijeka hub capacity, two scenarios were considered and then used for the projection of future traffic. The basis for the projection was the traffic forecast of the Port of Rijeka according to the Master plan [11] and the potential transit traffic from Zagreb to Trieste and in the opposite direction.

Considering the forecasts of traffic for certain types of cargo and the movements of good flows, two types of traffic projections were made. As the forecast for the basis of dimensioning of all the parameters for modernization and construction of railroads in Rijeka railway junction the variant showing high traffic flow scenario has been accepted.

Traffic forecast for 2031 according to these scenarios, in addition to the trends of increased traffic up to 2026, takes into account the planned construction of a new container port on the island of Krk, as well as higher traffic on the corridor between the Danube and the Adriatic region or of bulk cargo terminal in Bakar. The expansion of the gravitational area of the new high efficiency Rijeka-Zagreb railway is predicted as well as the construction of the part of the future Adriatic-Ionian railway. After the construction of a new Rijeka-Zagreb railway and a new railroad of lowland features from Rijeka to Trieste, substantial transit traffic through the Rijeka junction can be expected. This would generate advantageous transport connections for transit traffic from Eastern Europe towards Italy, Switzerland, France and the Netherlands in relation to the existing rail link through Slovenia, that is, through Ljubljana and Divača.

Table 1 shows the forecast of railway traffic, which consists of port traffic, traffic of other users of the railway system and transit traffic through the railway junction. The traffic projection on the connecting railways of Rijeka railway junction, in the direction of Zagreb and Slovenia is shown as well.

Given the expected substantial increase in container traffic in the Port of Rijeka, the transhipment amounts of containers at each ship and the uneven- 
Table 1 - Railway traffic forecast - high scenario (in 000 t)

\begin{tabular}{||l|c|c|c|c||}
\hline \multicolumn{1}{|c|}{ Year } & 2006 & 2016 & 2026 & 2031 \\
\hline \hline The Port of Rijeka & 2.613 & 11.417 & 17.619 & 29.450 \\
\hline Other junction users' traffic & 250 & 500 & 1.000 & 1.250 \\
\hline $\begin{array}{l}\text { Transit (from the direction of South-eastern } \\
\text { Europe towards North-western Europe) }\end{array}$ & & 1.000 & 5.500 & 7.000 \\
\hline Total Railway & 2.863 & 12.917 & 24.119 & 37.700 \\
\hline Total railway-direction south-east (Zagreb, Split etc.) & 2.291 & 11.317 & 18.019 & 30.100 \\
\hline Total railway-direction west (Slovenia, Italy, Austria etc.) & 572 & 1.600 & 6.100 & 7.600 \\
\hline
\end{tabular}

Source: Rijeka railway traffic system: Analysis of the current condition of the Rijeka railway traffic system and development possibilities by 2040, Željezničko projektno društvo d.d., Zagreb, 2009

ness of docking for container terminal ships will increase. Consequently, in some situations there will be the need for intensive container transport, which will require large transport capacity for shipping/delivery of cargo. In these conditions, the railway transport has got an advantage over road transport because of greater capacity and lower transport rates.

According to forecast, average daily shipping would in both directions be over 3,200 containers. In order for the given amount of traffic to be shipped/delivered, the reconstruction of Rijeka railway junction is required, with increase in capacity, which includes the construction of a new high-efficiency Rijeka-Zagreb railway line.

\section{MAIN DETERMINANTS OF THE REDEFINED RIJEKA RAILWAY JUNCTION}

The Rijeka railway junction borders on the south side with the port, while on the northern and eastern sides with urban residential areas and on the west side with industrial plants. The redefined concept of the junction represents the implementation of passenger transport facilities in the urban area while the capacity for cargo transport would be mainly located in peripheral locations such as Krasica, Kukuljanovo, Bakar, Ivani, Bršica, Island of Krk and others.

The Rijeka rail junction will be limited on the west side by Učka tunnel, by Raša and the Port of Bršica, on the northern side by the double-track railway line Jurdani-Škrljevo and also by means of a new railway bypass. The junction should end on the eastern side at the Škrljevo station on the existing railway line and it will include new stations of Ivani, Krasica and Island of Krk on the new rail tracks.

Within the Rijeka railway junction the building of three logistic centers is planned, with each one having its own specifics and characteristics. The first one should be the Škrljevo- Kukuljanovo port-industrial centre, the second one should be the logistic and distribution centre Miklavja of Matulji municipality on the plateau above Jurdani, and the third one would be placed within the industrial and economic zone on the Island of Krk near the future port facilities. In order to make effective both the shipment and cargo delivery, the above mentioned centres should be connected to railroad network in both directions, to the interior and within the rail junction itself.

\subsection{Eastern part of Rijeka railway junction}

The new high efficiency Rijeka-Zagreb railroad ends at Ivani station where it connects with the bulk cargo terminal in Bakar, the container terminal of Brajdica as well as with other terminals of the port. After the construction of the new railway, the Ivani and Krasica stations take on a new function by becoming its first and final section.

Technical and technological features of the new railway route (inclination of $12.5 \%$ and minimum bending radius of $3,000 \mathrm{~m}$ ) allow the cargo transport trains of 2,000 to 3,800 t of weight and up to $750 \mathrm{~m}$ of length by using the double traction system. On the other hand, the characteristics of the existing railroad tracks that connect the present port basins (Bakar, Sušak and Rijeka) with the Krasica station, are quite unfavourable (inclination of $25-28 \%$ and a minimum bend radius of $275-300 \mathrm{~m}$ ) and consequently enable traffic of cargo trains of 500-1,000t weight and up to $360 \mathrm{~m}$ length. The introduction of double traction system will enable traffic of trains of 1,500 t of weight.

The Ivani station is located next to the railway line and has one-way connection to the railroad, while its separation from the railroad Škrljevo-Bakar is performed by a separated crossover. The new function of the station will include the preparation and distribution of trains to/from other railway capacities into the Rijeka rail junction. The railroad that will connect Ivani and Krasica stations will have the same technical and technological characteristics as the new high-efficiency Rijeka-Zagreb line. So the railway inclination from Ivani station to Krasica will not exceed $12.5 \%$, that is $14 \mathrm{daN} / \mathrm{t}$ of resistance. The station Ivani, as well as the Krasica station, provide the possibility of stacking trains in the direction of the interior, and thus enable 


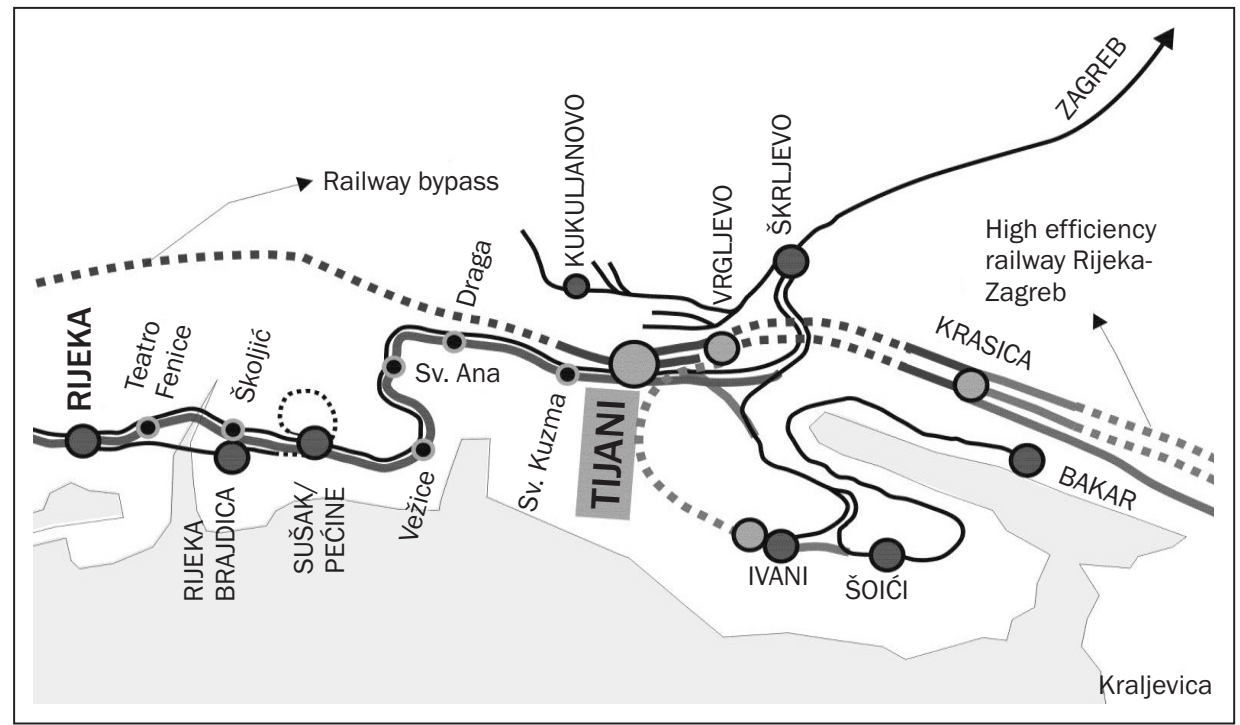

Figure 1 - Location of Tijani station on the railroads of western side of Rijeka junction

Source: Riječki željeznički prometni sustav: Analiza postojećeg stanja riječkog željezničkog prometnog sustava i razvojne mogućnosti do 2040. godine, Željezničko projektno društvo d.d., Zagreb, 2009.

mutual complementation and changing of the stations during the transport operations.

The Tijani train station will be a turnout point for the new high-efficiency Rijeka-Zagreb railway line and the existing Rijeka railway line, and it will also be a starting point of future Rijeka bypass Tijani-OpatijaMatulji. This station will be used for controlling traffic from Krasica or Škrljevo, to Ivani and the existing railway line. After leaving Tijani, a line route passes through a 330m long tunnel and further continues under the existing Zagreb-Rijeka railway line and the Škrljevo-Bakar railway line. After a 400m-long tunnel, the railway route follows the terrain at an elevation of $+200 \mathrm{~m}$ above sea level until the entrance into a third tunnel $(155 \mathrm{~m})$ and then comes to the freight train station Krasica. On the Tijani-Krasica railway route there are three bend radii, $\mathrm{R}_{1}=2,000 \mathrm{~m}, \mathrm{R}_{2}=1,000 \mathrm{~m}$ and $\mathrm{R}_{3}=700 \mathrm{~m}$. In Tijani, the railway line is located at an elevation of +201 meters above sea level, and at Krasica station at an elevation of +190 meters above sea level. In the above railway section, the maximum slope of railway line is $10 \%$.

The arrival of a new railroad in the Rijeka railway junction is scheduled to be carried out through Novi Vinodolski and Crikvenica with longitudinal entry into the future cargo terminal at Krasica. As Krasica is the starting and ending station of the new railway system, it is very important since it will make it through the regulation of traffic on the railroad and it will determine the distribution of trains within the Rijeka hub. The railroad from Krasica to Rijeka will be brought through the tunnel under Škrljevo and by connection to the old Zagreb-Rijeka railroad at Tijani.

The future railway to Krasica station has lowland characteristics since the axial tilt in the Drežnica and
Skradnik stations direction is $8 \mathrm{~mm} / \mathrm{m}$, while from the station to the Rijeka junction the tilt of axis amounts to more than $25 \mathrm{~mm} / \mathrm{m}$ [14]. Therefore, the cargo terminal of Krasica station will determine the composition of larger units of trains in direction of the new tracks (trains of mass of 1,800 - 3,600t and 750m of length) from smaller train units (trains of 750 1,500t and 360 - 450m of length) which come from the loading sites in the Rijeka junction (Bakar, Rijeka Brajdica, Škrljevo). On the other hand, from the larger train units that come from the interior, smaller trains will be composed and directed to the destination locations within the Rijeka hub. Thus, the role of Krasica freight train station would consist of amortization between the large capacity of the new lowland double-track railway line and the capacity of the railway lines within the junction. The planned route of the new double-track railway line from Krasica station toward the future container terminal on the Island of Krk and Omišalj station begins at the elevation of 183 metres above sea level and descends on the new Krk Bridge down to the elevation of 67 metres above sea level. The above railway line has the lowland characteristics since the largest decrease in the slope will amount to $10 \%$, and the total resistance of the line from 12.5 to 14 daN/t. Therefore, the pulling of trains from the Island of Krk would be exercised without dismantling, but rather by simply changing direction towards the interior and vice versa.

One of the key facilities of Rijeka railway junction would be the Krk railway bridge, located east of the existing bridge. The construction of a branch line towards the Rijeka airport is planned, which would, aside its function of passenger traffic, in the future also have the purpose of freight traffic. Crossing of 
the railway line to the Island of Krk will enable the transport of passengers from the airport to Rijeka and vice versa, and will provide good traffic connection of the entire region with the air traffic system. The Omišalj station will be the starting station towards a new high-efficiency Rijeka-Zagreb railway line from the direction of the Island of Krk and the new container terminal.

\subsection{Urban and suburban transport}

The redefined Rijeka railway junction anticipates the implementation of a railway which would pass through the city and the tracks of which would be moved from Permani and Matulji junctions westwards to the location of Tijani near Draga eastwards.

The city railway would connect the western and the eastern part of Rijeka. The urban and suburban passenger traffic would move along the main longitudinal junction direction from Škrljevo to Jurdani, and in the future to Jadranovo, Crikvenica and Novi Vinodolski. The existing railway line would be used mainly for passenger traffic, while the new lowland railway line would predominantly have freight role. The railway line would include four railway stations, these being at Škurinje, above Zamet, and between Matulji and Ćikovići.

The planned route of the railway line is located along the corridor on which some of the existing bus lines operate. In some bus lines the corridors correspond entirely, while in some lines they coincide in their majority. The introduction of railway in the urban and suburban traffic of the city of Rijeka would significantly increase the number of passengers in the junction on the Škrljevo-Rijeka-Opatija-Matulji line, which would contribute to the unburdening of road traffic.

The implementation of urban and suburban railway lines should be introduced in stages. According to the dynamic construction plan, three stages are predicted, and each of them would for itself represent a technical and technological unit [14]. The first stage of implementation can be realized by using the existing capacities with improvement of technical conditions on the railway line and the purchase of more modern means of transport. The passenger station in Rijeka, in addition to the existing function of the centre of intercity and international traffic, will become the main centre of urban and suburban traffic. In the final phase of the project realization, the Škrljevo-Jurdani line will be the carrier of urban and suburban travel while the bus traffic, in addition to line functions, will supply the railway lines.

The new Rijeka railway bypass is significant because of its possibility of adapting to the urban and suburban transport of passengers. The planned "Elevation 200" is determined by the height position of Tijani (200m above sea level) and Matulji (211m above sea level), and the continuation of its construction from Matulji through the tunnel of Učka to Istria is in the function of transit traffic from Trieste and Koper to Zagreb and Dubrovnik.

\subsection{Connection to Istria}

The construction of railway infrastructure which will connect Rijeka railway junction with Istria through the tunnel of Učka is important in the context of the establishment of a traffic connection from the Port of Rijeka to Koper and Trieste.

The new Rijeka-Koper-Trieste railway line, as a part of the Adriatic-Ionian corridor, will link Pan-European corridor $\mathrm{V}$ and corridor $\mathrm{V}$ Branch $\mathrm{B}$, and will in this way contribute to the establishment of the northern Adriatic ports system. The construction of a new railway track and a new tunnel through Učka predicts the shortening of travel time to Pula from the current 6 hours (transport by rail bypass via Ljubljana and Pivka or combined transport train-bus-train) to approximately 3.5 hours. Also, the railway connection between Zagreb and Trieste via new Rijeka railway and a new railway track through Istria shortens the travel time by approximately 1 hour in freight traffic and 2 to 3 hours in passenger traffic compared to the existing railway connection through Ljubljana. The length of the railway distance Zagreb-Rijeka-Trieste after the realization of these projects would be $251 \mathrm{~km}$.

The first ideas about a railway track through Učka date back to 1886 . In terms of the construction, the first preparatory actions for breaking through the mount of Učka near Poljane were made in 1951 (a tunnel $6,700 \mathrm{~m}$ long) and the preparatory actions for the breakthrough of the tunnel Ćićarija were carried out in 1993.

Although previous projects adopted the tunnel Ćićarija of $14,370 \mathrm{~m}$ in length, the current projects plan the construction of the tunnel of Učka. By the predicted variant, the railway connection with Istria is realized from Opatija-Matulji Station located at an elevation of $211 \mathrm{~m}$, which is $130 \mathrm{~m}$ below Jurdani Station, which was planned in the tunnel Ćićarija variant. After the Matulji Station, the track goes over a 200m long viaduct into the tunnel Učka.

The Učka variant plans the realization of the project of building a $12,030 \mathrm{~m}$ long tunnel, which is 2,350 meters shorter than the tunnel through Ćićarija. The given variant, according to Table 2 establishes also shorter connections with Pula, Raša and Trieste. The existing railway distance from Rijeka to Pula would thus be shortened by $52 \%$, and to Raša, or Bršica, by $62 \%$. For valuation of the Pan-European Transport Corridor $V$ it further provides, in terms of finished level and track direction, more efficient railway connection from Rijeka to Koper and Trieste. 
Table 2 - Railway distances from Rijeka to Pula, Raša and Trieste comparing alternative tunnel routes (in km)

\begin{tabular}{||l|c|c|c||}
\hline \multicolumn{1}{|c|}{ Relation } & $\begin{array}{c}\text { Current } \\
\text { state }\end{array}$ & $\begin{array}{c}\text { Učka } \\
\text { route }\end{array}$ & $\begin{array}{c}\text { Ćićarija } \\
\text { route }\end{array}$ \\
\hline \hline Rijeka - Pula & 200 & 95 & 106 \\
\hline Rijeka - Raša & 179 & 68 & 90 \\
\hline Rijeka - Trieste & 124 & 84 & 106 \\
\hline
\end{tabular}

Source: authors

Immediately after exiting the tunnel of Učka, the railway goes over a short viaduct $(100 \mathrm{~m})$ into a $800 \mathrm{~m}$ long tunnel, and exits onto flat terrain where the construction of Vranje Station is planned. It is the west pre-station of Rijeka railway junction where the tracks from Rijeka, Pula (direct connection to the Borut Station), Lupoglav and Divača, and the planned main railway line from Trieste come into contact.

Exiting the Vranje Station, after passing through a 930m long tunnel, through an approximately 1,000m long viaduct the railway route climbs, with an inclination of up to $18 \%$, towards the Borut Station. The smallest bend radius in that part is $R=700 \mathrm{~m}$, and the predicted driving speed is up to $120 \mathrm{~km} / \mathrm{h}$. The planned distance between the Matulji Station and the Borut Station is $23.3 \mathrm{~km}$, while the distance between the stations at Matulji and Vranje is $15.5 \mathrm{~km}$. At the entrance to the Borut Station the establishment of direct track connection northwards toward Lupoglav and Divača is planned.

\section{CONSTRUCTION AND MODERNIZATION PHASES OF THE RIJEKA RAILWAY JUNCTION}

In accordance with the plans of development of the Port of Rijeka and the Traffic development strategy of the Republic of Croatia, the construction and modernization phases of the Rijeka railway junction have been defined [14].

The development plan of the Rijeka railway junction consists of four phases while the dynamic plan of reconstruction and construction plans the project completion in over 20 years. It is important to mention that the schedule of activities within various phases can vary from the one given below, depending on the financial resources available for the investment as well as on the priorities in a given moment.

The first phase shall be completed by 2012. It mostly consists of the modernization of the existing railway capacity. Among other things, the following activities have been planned:

- reconstruction of the Rijeka cargo station and reconstruction of the passenger station, as well as construction of the third platform,

- reconstruction of the Rijeka Brajdica station according to the planned container terminal extension,
- railways extension and harmonisation of capacities at Brajdica railway station deriving from the container terminal extension,

- incorporating ETCS into the railway junction,

- installing signalling and security electronic devices in Rijeka, Rijeka Brajdica, Opatija Matulji, Jurdani and Šapjane stations,

- replacement of railway power networks ŠkrljevoBakar and Škrljevo-Rijeka-Šapjane,

- installing an optical cable into the railway junction,

- begin construction of the Ivani station,

- first phase of construction of the urban and suburban transport station.

The second phase shall run from 2012 to 2017, or to the completed construction of the new high-efficiency Rijeka-Zagreb railroad. The following major projects have been planned:

- reconstruction of the second track of the railways Škrljevo-Rijeka and Rijeka-Opatija/Matulji,

- reconstruction of the cargo station Rijeka and modifications and construction of the new container terminal at Zagreb quay,

- second phase of the construction of urban and suburban transport station,

- reconstruction of a track in Bakar (together with connecting the $1^{\text {st }}$ track) and a track in Kukuljanovo in accordance with traffic increase within the Rijeka junction,

- construction of a shunting group of tracks and a station for cleaning and washing passenger wagons at Ivani station,

- construction of a new railway terminal for general cargo in Škrljevo/Kukuljanovo area in order to substitute the Rijeka terminal which shall be used as a new bus central station.

In accordance with a dynamic plan of development, the third phase shall run from 2017 to 2022. The following activities have been planned:

- completion of the new high-efficiency Rijeka-Zagreb railroad,

- connection of a newly built railroad and the existing railroads within the Rijeka railway junction by constructing the Krasica, Tijani and Vrgljevo stations, and the Glavani bifurcation,

- construction of a connection railroad to the Ivani station in the west,

- completion of the Ivani station,

- construction of cargo and logistic Miklavja centre on the western part of the junction,

- completion of the station and tracks in a free-trade and industrial zone Kukuljanovo (R-27),

- construction of a multipurpose (road, railway and pipeline) bridge to the Island of Krk,

- construction of railway to the Island of Krk, the Krk island railroads, shunting station and a port station on the Island of Krk harmonised with a new container terminal, 


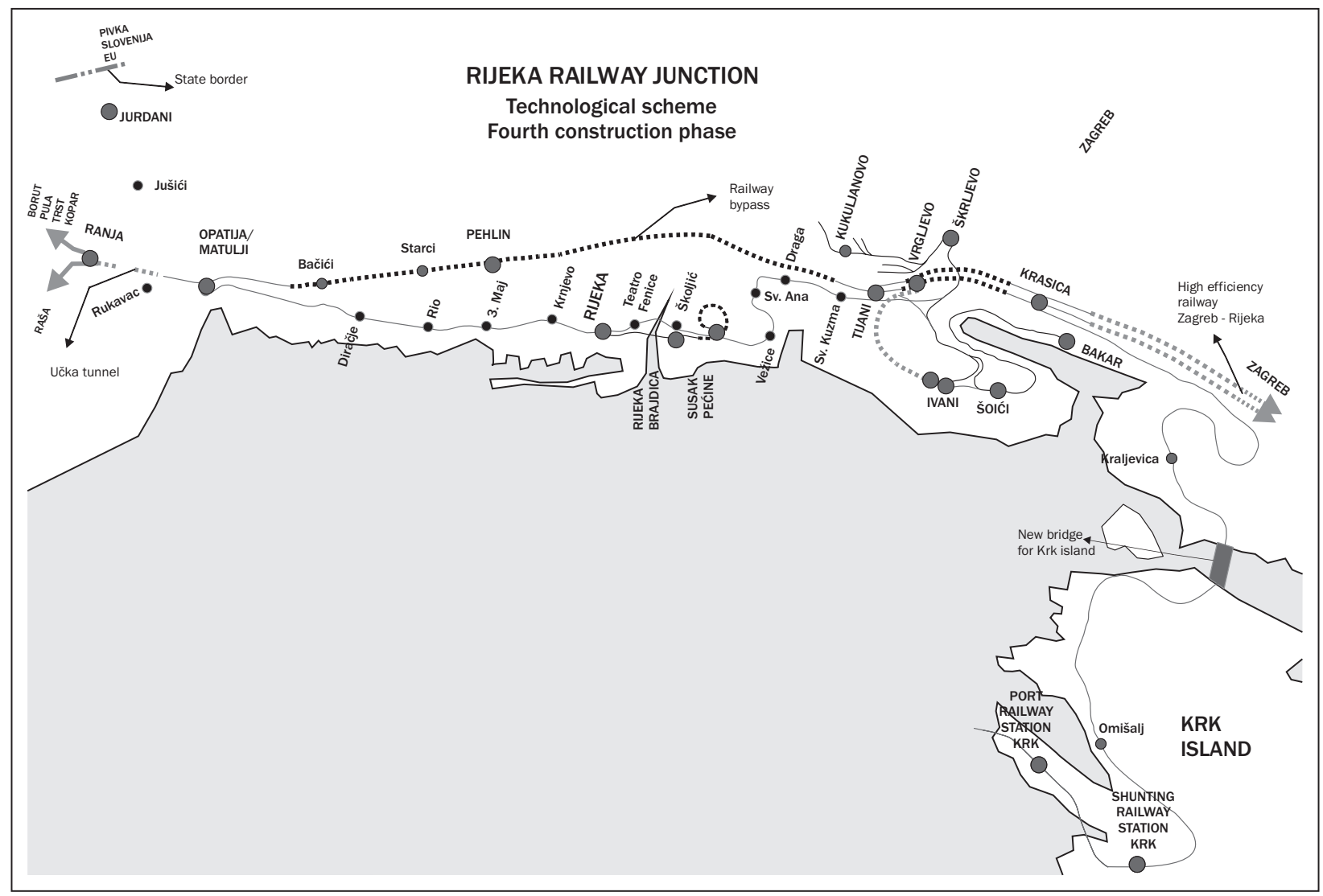

Figure 2 - Technological scheme of the Rijeka railway junction - fourth construction phase

Source: Riječki željeznički prometni sustav: Analiza postojećeg stanja riječkog željezničkog prometnog sustava i razvojne mogućnosti do 2040. godine, Željezničko projektno društvo d.d., Zagreb, 2009.

- construction of a station on the Krasica-the Island of Krk railroad,

- begin construction of the Učka railway tunnel, being the most demanding part of the Istra railway route.

The Fourth phase, planned for the period after 2022 or after the construction of a new high efficiency railway and the construction of a container terminal on the Island of Krk. This phase shall comprise the following:

- construction of the Rijeka railway bypass ("elevation 200") which shall comprise new passenger services,

- completion of the Učka railway tunnel and of the connections to the Istrian railway lines (Borut, Lupoglav and Raša),

- begin construction of a new railway from the Učka tunnel and Borut station to Koper and Trieste.

\section{IMPACT OF RAILWAY INFRASTRUCTURE MODERNIZATION ON THE PORT OF RIJEKA DEVELOPMENT}

Railway infrastructure and superstructure are among the basic elements of port technical equip- ment and reloading facilities, whose capacity and efficient operation determines the planned cargo transhipment. It can be stated that a prerequisite for further effective actions of Rijeka as a transit port for the Central European countries is the modernization of land transport connections between the hinterland and the port. By releasing into traffic the Rijeka-Zagreb motorway and the full profile of Rijeka Bypass a certain level of connectedness in road traffic efficiency has been reached, while connecting the Port of Rijeka with the railway infrastructure is not at the appropriate level. The existing railway lines do not meet modern technological and traffic demands. In addition to the existing inefficient Rijeka-Zagreb railway line, there are no direct railway connections between Rijeka and the railway lines in Istria and further with the ports of Koper and Trieste, as well as no direct railway connections with the Port of Ploče [7].

Construction and modernization of railway capacity should follow the dynamic development of the Port of Rijeka. The interdependence between the port and land connections with the hinterland will be solved by building new railroads linked to the Rijeka railway transport system.

The largest projects of redefined Rijeka railway junction are the construction of a new high-efficiency 
railway line Rijeka-Zagreb and the construction of a double-track railway line which will connect Rijeka with the ports of Koper and Trieste. The railway linking of the Pan-European Transport Corridor V and its Branch $B$ would enable the creation of the northern Adriatic ports system which could compete with the large ports of Northern and Western Europe. The implementation of these projects will significantly improve and make shorter the rail links between South-East Europe and its Central-Western side, and it will greatly improve the exploitation conditions of the Northern Adriatic transport route.

In a broader context, for the valorisation of the Port of Rijeka and the associated traffic route, connecting it to the major system of the European inland waterways Rhine-Main-Danube is of immense significance. For the realization of transport corridor the Danube region-the Adriatic as modern connection of the Port of Rijeka with Central European and Black Sea markets, it is necessary to perform the following projects: the construction of a new Rijeka-Zagreb railway line, restructuring the water route of the Sava river in order for it to reach the fourth class of navigation, the building of a second railway track between Zagreb and Sisak, the construction of multipurpose Danube-Sava canal and the reconstruction of Rijeka and Zagreb railway junctions. In this way, a combined transport corridor 566.9 kilometres long between the ports of Rijeka and Vukovar is established. This route connects the Danube Corridor VII, the Pan-European Corridor X and Corridor V, branch B of the Pan-European Transport Corridor [6].

Future development of Rijeka traffic junction would be significantly influenced by listing the Central European Transport Corridor-Route 65, which connects the northern Adriatic Sea with the Baltic, into the TEN-T network. From a traffic and strategic point of view, the creation and implementation of a new Central European Corridor is of great importance. The Danube Corridor has become a bottleneck for traffic of Central European countries which are looking for new capacities for their traffic demand, while the main European and global participants in international logistics are looking for solutions to route cargo flows in the area of the new Central European Transport Corridor.

Although it had been considered that the planned Corridor-Route 65 was set over Slovenia toward the ports of Koper and Trieste, or even over Bosnia and Herzegovina toward the Port of Ploče, in the end, the transport route through the Republic of Croatia towards the Port of Rijeka was accepted, which will make it the key transport junction of the new Corridor. The new Corridor presupposes a modern intermodal transportation system, in which, in the structure of freight transport, the railway and inland waterways traffic will participate with approximately 85 percent, and road traffic with up to 15 percent.
The modernization of Rijeka railway junction is by its interaction associated with the development of the Port of Rijeka. The planned development strategy of the Port of Rijeka can not be achieved without the adequate modernization of railway facilities and the construction of the corresponding railway tracks. Also, the plans for the construction of the high-capacity railway network have no purpose if they are not in agreement with the plans of modernization of the Port.

\section{CONCLUSION}

The Rijeka railway junction is still a bottleneck of the Port of Rijeka and the Pan-European branch $V_{B}$. The junction needs urgent reconstruction and at the same time requires the construction of new high-quality railway routes to the inland, all in line with the existing knowledge of the railway transport technology which shall go side by side with a long-term development of the Rijeka port system. The reconstruction and construction of the existing railway junctions require harmonising the development projects for all means of transport, taking into consideration technical, technological, urbanistic and economic conditions.

Within the integrated transport studies of the Coast-Mountain County the role of the rail junction has been redefined and a new conceptual solution in accordance with the new conditions and requirements has been offered.

According to the proposed concept the passenger rail transport will be integrated into urban area while the infrastructure for cargo transport should be mostly located in peripheral and border locations of the rail junction such as: Krasica, Kukuljanovo, Bakar, Ivani, Bršica and the Island of Krk.

In its final phase, the Rijeka railway junction will be bound on the west side by the Učka tunnel, Raša and by the Port of Bršica, on the northern side by the double tracked railway Škrljevo-Jurdani and by the new railway bypass at 200 elevation. The eastern part of the junction will include new stations of Ivani, Krasica and the Island of Krk, and its completion will be at the Škrljevo station on the existing track.

In accordance with the basic settings the technology and work organization changes within the railway junction and on the access lines, this is primarily related to the volume ranking that is significantly reduced. The entire traffic organization on the rail line and on the junction will vary due to goods structure change, and considering the increased container traffic.

The new rail connection with Istria and further construction of the railway to Koper and Trieste are important for the Pan-European V transport corridor evaluation linking the three largest North Adriatic Ports. For the development of the Rijeka transport junction, in addition to the new railway through the Učka tunnel, 
the construction of a new high-efficiency Rijeka-Zagreb railway line is of great importance.

\section{Mr. sc. SINIŠA VILKE}

E-mail: svilke@pfri.hr

LIVIA ŠANTIĆ, dipl. inž.

E-mail: livia@pfri.hr

Sveučilište u Rijeci, Pomorski fakultet

Studentska 2, 51000 Rijeka, Hrvatska

Mr. SC. MATIJA GLAD

E-mail: matija.glad@hrvatske-ceste.hr

Hrvatske ceste d.o.o.

Vončinina 3, 10000 Zagreb, Hrvatska

\section{SAŽETAK}

\section{REDEFINIRANJE ŽELJEZNIČKOG ČVORA RIJEKA}

U radu je prikazan i analiziran redefinirani željeznički čvor Rijeka. U kontekstu međuzavisnosti luke i željeznice redefinirana koncepcija riječkog željezničkog čvora nalaže smještaj kapaciteta za teretni promet na perifernim lokacijama, kao što su Krasica, Kukuljanovo, Bakar, Ivani, Bršica i Krk dok bi putnički promet bio implementiran u gradski prostor. Najznačajniji projekti vezani za riječki željeznički prometn sustav su izgradnja nove pruge visoke učinkovitosti Zagreb Rijeka te pruge kroz tunel Učku, koja će u budućnosti povezivati luke Rijeku, Kopar i Trst. Pored rekonstrukcije teretnih kolodvora Rijeka i Brajdica, dogradnje drugog kolosijeka na prugama Škrljevo-Rijeka i Rijeka-Opatija/Matulji, izgradnje kolodvora Krasica, Ivani, Tijani i Vrgljevo, ističu se izgradnja višenamjenskog mosta za otok Krk i željezničke pruge do novog kontejnerskog terminala te izgradnja riječke željezničke obilaznice na "koti 200".

\section{KLUČ̌NE RIJEČI}

željeznički čvor Rijeka, željeznički prometni sustav, željeznički promet

\section{LITERATURE}

\section{Articles:}

[1] Baričević, H.: Tehničko-tehnološka revalorizacija željezničkog čvora Rijeka, Proceedings of the Maritime Faculty, year 7, Vol.1, pp. 13-22, 1993
[2] Blašković Zavada, J., Badanjak, D., Brnjac N.: Integration of the Railway line in Corridor $V_{B}$ in the Traffic System of Croatia and Europe, Promet, Vol. 17, 5, pp. 235-243, Zagreb, 2005

[3] Božičević, J.: Prometna valorizacija Hrvatske (Traffic Evaluation of Croatia), Scientific Council for Traffic HAZU, Zagreb, 1992

[4] Božičević, J.: Razvitak hrvatskog gospodarstva sa stajališta razvitka prometa, Ekonomski pregled, 52 (78), pp. 753-773, 2001

[5] Brkić, A. et al.: Elementi tehnologije i razvoja hrvatskih željeznica za 21. stoljeće, Suvremeni promet, 17 (1-2), pp. 102-107, 1997

[6] Dundović, č., Vilke, S.: Izgradnja višenamjenskog kanala Dunav - Sava u funkciji prometne integracije Podunavlja i Jadrana, Pomorstvo - Journal of Maritime Studies, year 23, No. 2 (2009).

[7] Dundović, Č., Vilke, S., Šantić, L.: Značenje željezničke pruge visoke učinkovitosti Zagreb - Rijeka za razvoj riječke luke, Pomorstvo, year 24, No.2, Rijeka, 2010

[8] Hlača, B., Rudić D., Hirnig, S.: Rail transport - an important factor in the Port of Rijeka development, Promet, Vol. 22, 5, pp. 379-388, Zagreb, 2010

[9] Stipetić, A., Blašković Zavada, J.: Influence of Railway Traffic on the Pan-European Corridor $V_{B}$ on the Development of the Port of Rijeka, Promet, Vol. 18, 5, pp. 327-335, Zagreb, 2006

[10] Vilke, S.: Koncepcija razvitka sjevernojadranskih luka Rijeke, Kopra i Trsta, Pomorski zbornik, year 43, Rijeka, 2005

Studies and reports:

[11] Luka Rijeka, Master plan, Rotterdam Maritime Group, 2008.

[12] Modernizacija i izgradnja željezničke pruge Državna granica - Botovo - Zagreb - Rijeka - Studija opravdanosti, HŽ Infrastruktura, IGH d.d., Željezničko projektno društvo d.d., Zagreb, 2009

[13] Nacionalni program izgradnje i održavanja željezničke infrastrukture za razdoblje od 2008. do 2012. godine, Croatian Parliament, 2008

[14] Riječki željeznički prometni sustav: Analiza postojećeg stanja riječkog željezničkog prometnog sustava i razvojne mogućnosti do 2040. godine, Željezničko projektno društvo d.d., Zagreb, 2009

[15] Strategija prometnog razvitka $\mathrm{RH}$ (Croatian strategic development), Zagreb, Ministry of Sea, Transport and Communications, 1999 